\title{
19 Comparing regulatory oversight bodies across the Atlantic: the Office of Information and Regulatory Affairs in the US and the Impact Assessment Board in the EU
}

\author{
Jonathan B. Wiener and Alberto Alemanno
}

'Quis custodiet ipsos custodes?' asked the Roman poet Juvenal - 'who will watch the watchers, who will guard the guardians?' ${ }^{1}$ As legislative and regulatory processes around the globe progressively put greater emphasis on impact assessment and accountability, (Verschuuren and van Gestel 2009, Hahn and Tetlock 2007), we ask: who oversees the regulators? Although regulation can often be necessary and beneficial, it can also impose its own costs. As a result, many governments have embraced, or are considering embracing, regulatory oversight - frequently relying on economic analysis as a tool of evaluation. We are especially interested in the emergence over the last four decades of a new set of institutional actors, the Regulatory Oversight Bodies (ROBs). These bodies tend to be located in the executive (or sometimes the legislative) branch of government. They review the flow of new regulations using impact assessment and benefit-cost analysis, and they sometimes also appraise existing regulations to measure and reduce regulatory burdens. Through these procedures of regulatory review, ROBs have become an integral aspect not only of regulatory reform programs in many countries, but also of their respective administrative systems.

Although most academic attention focuses on the analytical tools used to improve the quality of legislation, such as regulatory impact assessment (RIA) or benefit-cost analysis, this chapter instead identifies the key concepts and issues surrounding the establishment and operation of ROBs across governance systems. It does so by examining and comparing the oversight mechanisms that have been established in the United States and in the EU and by critically looking into their origins, rationales, mandates, institutional designs and scope of oversight.

\section{The rationale for the establishment of ROBs}

\subsection{Why oversee the regulators?}

Wherever societies engage in economic activity (which is to say everywhere), demand arises for regulation by the state to curb the undesirable impacts of that activity. In the real world of imperfect markets, regulations can be necessary to correct market failures such as externalities (e.g. health, safety and environmental risks), asymmetric

1 Juvenal was asking who would oversee those assigned to guard the queen's fidelity during the king's absence, lest those guards betray their own duty. See Satires, Book 2: Satire VI, 6.029-34. 
information (e.g. in financial or labor markets), and market power (e.g. entry barriers), as well as correcting other problems such as unfair discrimination.

Although regulation can solve such social problems, it can also impose its own problems, including compliance costs, inhibition of innovation, ancillary risks, and rentseeking. Regulators may make mistakes, may choose poorly designed regulations, may neglect social goals other than their own narrow mission (Breyer 1993), ${ }^{2}$ may neglect the adverse impacts of their decisions, may aggrandise their own power, or may serve the interests of narrow groups rather than promoting broader public well-being (Kolko 1965, Ackerman and Hassler 1981). Regulators may pursue policies that reduce some risks while introducing new risks or shifting risks to other populations (risk-risk tradeoffs), where regulators are hampered by limited information, bounded decision domains, or the omitted voice of the affected populations (Graham and Wiener 1995). Political scientists and institutional economists have emphasized that in democracies, government decisions are not taken by a single ruler but instead represent a complex aggregation of preferences advocated by specific interest groups and often mediated through contending institutions. Because learning about issues and expressing political voice are costly, the shared general interests of the public at large may go underrepresented while the narrow interests of pressure groups are trumpeted (Olson 1971, Wiener and Richman 2010). ${ }^{3}$

As a result, wherever states deploy regulation, demand arises for oversight of the regulatory system to reduce the costs and side effects of regulation, promote efficiency in standard-setting and instrument choice, encourage consistency and transparency, ensure accountability, and improve the overall social outcomes of regulation. Regulatory oversight, particularly oversight by a centralized governmental body, has increasingly been seen as an effective mechanism for improving regulation. Regulatory oversight can be defined as 'hierarchical supervision of regulatory action by executive and legislative actors' (Lindseth et al. 2008: 3).

\subsection{How to oversee the regulators?}

The aim of regulatory oversight is both democratic and technocratic: to enhance the accountability of regulatory agencies to democratically elected officials, and to use analytic methods to improve the overall social outcomes of regulation by reducing the costs and side effects and increasing the benefits. Regulatory oversight, as it is generally carried out, uses several analytical tools which are heavily informed by economic analysis. The analytic tools that are generally employed have been discussed at length in the academic literature (Revesz and Livermore 2008, Graham 2008, Adler and Posner 2001, Adler and Posner 2006), and also in several OECD reports (Deighton-Smith 2007, 2006, OECD 2009). These tools include: impact assessment (IA) of proposed legislation; ${ }^{4}$

2 This may occur, for example, where regulators are pushed by legislatures or advocacy groups, such as consumer and environmental groups, to regulate despite (or overlooking) the social costs, or where regulators overestimate the risk to be regulated. See Breyer (1993).

3 A classic on this point is Olson (1971). For further discussion of the political economy of regulatory design, see Wiener and Barak Richman (2010).

4 IA can be defined as the process of systematic analysis of the likely impacts of a policy or intervention by public authorities. It may employ each of the analytic tools noted here. An IA also refers to the report or document containing such an analysis. 
benefit-cost analysis (BCA) and cost-effectiveness analysis (Graham 2008, Revesz and Livermore 2008, Wiener 2006); ${ }^{5}$ risk-risk tradeoff analysis (Graham and Wiener 1995, Revesz and Livermore 2008), ${ }^{6}$ and scientific analyses (Bagley and Revesz 2006). ${ }^{7}$ Other tasks may involve simplification of existing legislation and regulation (through codification, recasting, and repeal) (Beslier and Lavaggi 2006); consultation procedures on drafting proposals $;{ }^{8}$ screening and withdrawal of pending proposals; $; 9$ and monitoring and reducing administrative burdens. ${ }^{10}$

\subsection{Who oversees the regulators?}

The analytical tools and methodologies that are typically employed in regulatory oversight could, in principle, be employed by a variety of actors, including legislatures or their accountability arms, courts, auditors, executive officials, advisory bodies, review commissions, and non-governmental organizations. The distinctive institutional development of the past four decades in the US and during the past decade in Europe has been the emergence of regulatory oversight bodies (ROBs) to 'watch the watchers'. A typical ROB is an office in the executive branch (center of government) charged with supervising regulation government-wide. Some countries also have ROBs in the parliament or legislature. As shown below, both the US and the EU centralize regulatory oversight functions within the executive branch, though under different institutional designs.

One key attribute of any ROB is expertise, in the form of a trained professional staff capable of undertaking technical evaluation of regulatory impacts and options. These staff may be economists, but also may include experts in other fields of social science, law and policy, life science and physical science. As Adam Smith observed, expertise can be an antidote to passion - to politicized distortions of regulation - or at least a means to reveal and make transparent the significant impacts, tradeoffs, and alternatives of regulatory choices and to inform decision makers and the public of the promises and pitfalls of regulation. By contrast, any ROB lacking expertise or headed by a non-expert political appointee may simply exercise politicized influence over expert regulators and thereby undercut the ROB's perceived legitimacy. ${ }^{11}$

5 While BCA compares benefits and costs, seeking to maximize net benefits, cost-effectiveness seeks to minimize cost for a given objective or maximize benefits for a given cost. For further discussion of degrees of quantification in IA, see Graham (2008), Revesz and Livermore (2008), and Wiener (2006).

6 Including both ancillary harms and ancillary benefits. See Graham and Wiener (1995), Revesz and Livermore (2008).

7 See Bagley and Revesz (2006) (advocating centralized coordination of agency science). The US Information Quality Act of 2001 calls for centralized review of the quality of agency data and publications.

8 Commission communication, 'General principles and minimum standards for consultation of interested parties by the Commission', COM(2002) 704 (hereinafter 'minimum standards'). See, on this initiative, Obradovic and Vizcaino (2006).

9 For an insightful analysis on this initiative in the EU, see Allio (2008).

10 See Commission Communication, 'Action programme for reducing administrative burdens in the EU', COM(2007) 23 final.

11 Judicial oversight generally involves generalist professionals who are not experts in one regulatory topic, but who are experts in administrative law, and who are ideally independent, 


\section{Comparative administrative law}

A second key attribute of any ROB is political accountability, such as accountability to the center of government (e.g. the President or Prime Minister) or to a powerful ministry (such as budget/finance), to ensure that regulation serves the program of these highlevel officials who are in turn accountable to the electorate (Lindseth et al. 2008, Bickel 1986, Tushnet 1995, Ackerman 1993, 1998). ${ }^{12}$ Political accountability enhances the ability of ROBs to influence regulators who also have their own political constituencies. Just as regulators need oversight, so too ROBs warrant oversight, by the President or Prime Minister, by the legislature or parliament, perhaps by courts, ${ }^{13}$ and by the public.

Any ROB faces possible tensions between these two key attributes. Expert technocratic criteria for regulation may or may not coincide with political democratic criteria. That is, the President's or Prime Minister's (or legislature's) policy program may differ from the experts' advice regarding the optimal policy (Shapiro 2006, Graham 2007b). In such cases, the ROB may need to explain its expert technical analysis to a political leader with a different priority and try to convince the leader to change course, or the ROB may help make the impacts and tradeoffs transparent while recognizing that the political leader's priority will override the ROB's expert technical analysis.

The ROB may have both a need for independence from political micro-management, to assure its neutrality and technocratic objectivity, and simultaneously a need to be close to power in order to have authority over other ministries and to carry forward the President's (or Prime Minister's) regulatory agenda (E. Kagan 2001). In some cases, this tension can become acute.

Like any government body, a ROB may seek external social support to maintain its own budget and influence. If that support comes predominantly from advocacy groups on one side of a debate (e.g. business groups), this may compromise the perceived legitimacy of the ROB's advice. Meanwhile, ROBs may also need to have their own external advisory bodies to offer useful insight and feedback, both on advances in technical analytic methods and on emerging issues in regulatory policy (OECD 2007a).

These internal and external tensions are partly mediated through the rules for the appointment and removal of ROB officials. Therefore, an analysis of ROBs needs to address questions such as: Who has the power to appoint and remove the head of the ROB? How does the power to appoint/remove officials affect the performance of the ROB? What kind of expertise does the ROB have, or should it have? How does the ROB use its expertise and its political position to influence regulatory quality and decisions? Should political officials instruct the ROB on particular regulatory decisions (and do they)? These are some of the questions that we address in the following sections, focusing on the US and EU experiences with ROBs.

maintaining their perceived legitimacy by being shielded from political influence via secure job tenure (though in reality judges may also be influenced by political affiliations).

12 See Lindseth et al. (2008). Judicial review is typically not accountable to the electorate, but rather derives its legitimacy from its independence from politics. Its influence is generally defined as counter-majoritarian.

13 In the US, the Office of Management and Budget (OMB)/Office of Information and Regulatory Affairs (OIRA) has not been subject to judicial review; Revesz and Livermore propose that OIRA's issuance of key oversight guidelines should be subject to judicial review similar to rulemaking by regulatory agencies. Revesz and Livermore (2008: 172). 


\section{Origins of ROBs}

A brief historical perspective can help to illustrate the origins and objectives of these bodies in OECD countries. In the past, countries with a Roman law tradition set up forms of ROBs, as part of Councils of State, as in France (Robineau and Truchet 2002) and Italy (Caretti and De Siervo 1996). These bodies served as advisors to the government on the legality of regulatory decisions. They were also the superior level of the administrative courts, so they also exercised an adjudicative role meant to protect governments and avoid litigation in the civil courts regarding specific regulations. For example, in France after the Revolution, the Conseil d'Etat and the system of administrative courts were designed to shield the administrative state from being unduly constrained by the separate system of civil courts; the civil court judges were viewed as more sympathetic to the monarchy, while the administrative courts were meant to be more sympathetic to the legislature and to its efforts to redistribute power and wealth in France after the Revolution. Today, the Conseil d'Etat, acting as both a court of appeals for the administrative courts and a supervisory body for the administrative state, brings significant expertise to bear on the legality of regulatory decisions (Breyer 1993, Part III). However, it does not review impact assessments of proposed new regulations prepared by regulatory agencies (Bouder 2008, Trosa 2008).

Modern ROBs, established since the 1970s, especially in common law countries such as the USA and UK, but also in other countries such as the Netherlands, and in the European Union, have a different origin. They were mainly created in response to stagnating economic conditions; a rising tide of regulation of health, safety and environmental risks; an accumulated array of economic regulation of sectors such as banking, communications, and transportation; and an academic literature on both the need for and problems with regulation.

\subsection{The origin of the US Office of Information and Regulatory Affairs}

In the late 18th century, the US Constitution's strategy of checks and balances among branches of government was designed to avoid the concentration of power that existed in monarchic regimes. By the 20th century, that foundational strategy continued to animate the evolution of regulatory oversight. The US Administrative Procedure Act (APA) enacted in 1946 was a response to the 'New Deal' expansion of federal regulation in the 1930s and 1940s. In turn, the US Executive Orders on regulatory impact assessment issued beginning in the 1970s were, in part, a response to the 'Great Society' expansion of health and environmental legislation in the 1960s and 1970s, as well as the slowing economy, accumulated economic regulation, and academic analysis. In 1978, President Jimmy Carter, a Democrat, issued Executive Order (EO) 12044, requiring economic analysis of new regulations, and he created the Regulatory Analysis Review Group (RARG), an interagency working group that gathered when needed to review these economic analyses. Then in 1980, the US Office of Information and Regulatory Affairs (OIRA) within the Office of Management and Budget (OMB) was established by the Paperwork Reduction Act of 1980. OIRA was thus located in the Executive Office of the President. The Administrator of OIRA is appointed by the President and, since the 1986 amendments to the Paperwork Reduction Act (Pub. L. 99-591), is subject to confirmation by the Senate. OIRA has approximately 50 expert non-political staff. Whereas the RARG had been an interagency group that met on occasion, OIRA is a standing centralized expert oversight body. 


\section{Comparative administrative law}

When Ronald Reagan (a Republican) became President in 1981, he promptly issued Executive Order (EO) 12291 (February 1981), formally giving OIRA the role and authority of a ROB. The Reagan EO required agencies to conduct regulatory impact assessments using benefit-cost analysis, to ensure that regulations' benefits 'outweigh' their costs, and to submit those IAs to OIRA for review, while giving OIRA the power to 'return' an unsatisfactory regulation or IA to the agency. Some viewed the EO as an intrusion into the agencies' duty to carry out statutory instructions from the Congress; but the EO expressly provided that it did not override statutes, and others replied that in any case the President still has the authority to manage the executive branch. It also received criticism from those who saw it as anti-regulatory. President George H.W. Bush continued OIRA's role under EO 12291.

After Bill Clinton, a Democrat, became President in 1993, there was much speculation that he might issue a new EO diminishing OIRA's role in regulatory oversight. Instead, Clinton's EO 12866 (September 1993) reaffirmed the basic role of OIRA in reviewing agencies' policy proposals and regulatory IAs using benefit-cost analysis. It replaced the word 'outweigh' with the word 'justify', thereby emphasizing the importance of qualitative as well as quantitative criteria, and orienting benefit-cost analysis to be 'a tool not a rule' - informing the considered judgments of publicly accountable officials, not dictating decisions arithmetically. Clinton's EO also broadened the scope of the impacts to be considered in IAs to include distributional impacts and ancillary impacts, and enhanced the transparency of OIRA review. The Clinton administration also issued best practice guidelines on preparing IAs.

George W. Bush was elected president in the contentious 2000 election, and soon speculation arose again that he might issue a new EO enhancing OIRA's oversight role. Instead, Bush retained Clinton's EO 12866 (with only minor modifications made in his second term, such as adding coverage of agency 'guidance documents' through EO 13422 in January 2007). During the Bush administration, OIRA also issued guidelines on the conduct of IA, notably through Circular A-4 in September 2003.

Just after his inauguration as President in January 2009, Barack Obama rescinded his predecessor's EO 13422, ${ }^{14}$ but left in place EO 12866 as issued by President Clinton. At the same time, President Obama also issued a request for recommendations on a new EO on regulatory oversight, listing several topics to be addressed, but implying that he would continue the basic approach of requiring regulatory review by OIRA. ${ }^{15}$ As of January 2010, he had not yet issued a new EO.

Thus, the creation and role of OIRA reflects a bipartisan consensus - at least among the US Presidents of the last four decades - that the executive branch needs tools to oversee the regulatory state and manage its choices, employing both expert analysis

\footnotetext{
1474 Fed. Reg. 6113 (February 4, 2009).

15 President Barack Obama, Memorandum of January 30, 2009 - Regulatory Review, 74 Fed. Reg. 5977 (published February 3, 2009). President Obama directed the the Office of Management and Budget (OMB), in consultation with representatives of regulatory agencies, to produce within 100 days a set of recommendations for a new Executive Order on regulatory review. OMB then invited public comment, 74 Fed. Reg. 8819 (February 26, 2009), and more than 180 public comments were received by April 20, 2009. These memoranda and the public comments received are posted at http://www.whitehouse.gov/omb/inforeg_regmatters/.
} 
and political accountability, regardless of which political party is in power (E. Kagan 2001).

\subsection{The origin of the EU's Impact Assessment Board}

In Europe, regulatory review was not formally established until after 2000. Nonetheless, this history reflects the same pattern seen in the US, in which the ROB is created in response to the growth of the regulatory state.

The European Union (EU) launched its formal impact assessment (IA) procedure in 2002 as a regulatory review system within the European Commission. This process scrutinizes the quality of IAs conducted by the Commission services (DirectoratesGeneral, or DGs) on proposals for new policies. From 2002 to 2006, these IAs were shared among the Commission; then in November 2006, an ROB was established to oversee the IA process: the EU Impact Assessment Board (IAB), located in the office of the Secretariat-General of the European Commission. The IAB grew out of the 'Better Regulation' initiative (Wiener 2006), which was spurred by the Lisbon Agenda and the Mandelkern Report of 2001. ${ }^{16}$ The Commission issued Impact Assessment Guidelines in 2003, revised them in 2005, and updated them in 2006, before they were replaced by new ones in $2009 .{ }^{17}$ The IAB's primary role is to oversee the quality of the IAs produced by the Directorates-General (DGs) when the latter propose new policies. The IAB is a five-member board made up of representatives from several DGs and chaired by the Deputy Secretary-General; this structure is more akin to the interagency RARG than to the standing body of OIRA with its single Administrator and permanent staff.

As in the US, albeit with a different institutional history and structure, the EU Better Regulation initiative and its Impact Assessment program, including the creation of the IAB, have been in part a response to the growth of EU-level regulation, notably following the 1987 Single European Act and the 1992 Maastricht Treaty (Alemanno 2008: 45-6). The EU's adoption of the IA review process was also a way to support the Lisbon strategy for economic advance. ${ }^{18}$ The setting up of the IAB drew lessons from the US, but also from the UK and Swedish examples, where significant improvements in the regulatory frameworks and deregulation had been seen as associated with renewed economic growth (Radaelli and De Francesco 2007). As in the US, regulatory oversight achieved a kind of bipartisan consensus in the EU: The EU Better Regulation initiative and the IA process have been supported through varying presidencies of the Commission, including both Presidents Romano Prodi and José Manuel Barroso, and have also been endorsed by the Council of the EU. ${ }^{19}$

16 The final Mandelkern report on Better Regulation was finalized in February 2001 and published on 13 November 2001.

17 European Commission, Impact Assessment Guidelines, SEC(2009) 92.

18 The EU Better Regulation strategy is a centerpiece of the renewed 'Lisbon Strategy', which aimed at turning Europe into the most competitive and dynamic knowledge-based economy in the world by 2010. See European Commission's 'Partnership for Growth and Jobs' - the renewed 'Lisbon Strategy' launched in Spring 2005.

19 Council of the European Union, Conclusions of the Competitiveness Council on Better Regulation, December 3-4, 2009. 


\subsection{Other examples of ROBs}

These trends have been mirrored in many other countries and jurisdictions, gradually spreading across almost all OECD countries. For example, the UK has had a Regulatory Impact Unit, followed by a Better Regulation Executive, with an advisory body called the Better Regulation Task Force; these were succeeded by the Better Regulation Commission in 2006, and in turn by the Risk and Regulation Advisory Council in 2008, as well as being accompanied by additional scrutiny from the National Audit Office, the Panel for Regulatory Accountability, and the House of Commons. The Netherlands program to reduce administrative costs was overseen by the Inter-ministerial Project Team (IPAL) in the Ministry of Finance, with external scrutiny by the Advisory Board on Administrative Burdens (ACTAL) (OECD 2007b). Countries such as Mexico, with COFEMER (Comisión Federal de Mejora Regulatoria) following the previous example of the Economic Deregulation Unit (UDE), and Korea have also set up ROBs, influenced by examples in other OECD countries and by advice from the OECD. At the EU level, the European Court of Auditors (an institution created to audit the EU budget) has also indicated some interest in performing a role in regulatory oversight.

\section{Structure: constitutional and institutional design of ROBs}

ROBs could in principle be located in any branch of government. Thus, they might be established within the executive/administrative branch (for example, as an interagency working group; as an office of the president or prime minister; as an independent government watchdog office such as an auditor or ombudsman or inspector general; or at a government ministry for reform of regulation or state reform); within the legislative branch (as a legislative committee or a technical body attached to the legislature); or within the judicial branch (indeed judicial review functions as a kind of ROB, with the authority to reject regulatory decisions, though typically without the expertise and routine oversight role of an executive branch $\mathrm{ROB}$ ). The function of ROBs may also be carried out, in part, by external advisory groups, national academies of science, or other external nongovernmental actors such as advocacy groups, think tanks, academic researchers, and the news media. Although such groups may be expert and may conduct and publicize their reviews of regulatory IAs, they typically lack the authority to determine choices by the regulators. Within a multi-level governance system such as a federal republic or supranational union, the tasks of ROBs may also be exercised by the member states of the Union or federation.

The choice among these locations is always a question of comparative institutional analysis: Which institution is best equipped and best placed to perform oversight in each system of governance? In making such choices, there may be tradeoffs among criteria such as expertise, authority, transparency, and political accountability. Different constitutional structures may thus warrant different optimal locations.

\subsection{The location of OIRA in the US structure of government}

In the US, the location of the main ROB, OIRA, is in the Executive Office of the President. The OIRA Administrator is appointed by the President, with confirmation by the Senate. The OIRA Administrator reports to the Director of Office of Management and Budget (OMB), and then to the President.

The location of OIRA reflects the horizontal separation of powers in the US federal 
government. OIRA enables the President to manage the regulatory powers deployed by the legislature (the Congress). In response to New Deal expansion of federal regulatory state, the courts were asked by petitioners to undertake judicial review of agency regulation. In 1946, Congress, with the enactment of the Administrative Procedure Act (APA), gave courts the authority to enforce provisions that required notice and public comment when agencies make rules, and to be sure that regulations are not 'arbitrary or capricious'. Three decades later, in response to the Great Society expansion of federal regulation in the $1960 \mathrm{~s}$, the courts intensified their review by allowing increased access to the courts for advocacy groups and by adopting the 'hard look' doctrine in the 1970s. But active judicial review of agency action was seen by presidents as insufficient, because judicial review is episodic, conducted by non-expert judges without staff resources, not always subject to benefit-cost criteria, and not accountable to the President's policy agenda. Meanwhile, federal regulatory agencies were a contested terrain in the US constitutional structure: they conduct executive branch functions (with heads appointed by the President with Senate confirmation), and are also agents of the Congress exercising delegated legislative power, and they may perform adjudicatory functions as well. ${ }^{20}$

Although OIRA's initial focus was on paperwork reduction - reducing the administrative burden of government requests for information - it soon took on a role in overseeing regulation. OIRA has substantially, although not exclusively, been oriented as a way for the executive to check or shape legislative (Congressional) pressure to regulate. But OIRA operates only at the second stage, reviewing agencies' implementing regulations, not reviewing the legislation initially enacted by the Congress itself. OIRA review has historically been aimed primarily (though not exclusively) at countering the agencies' mission-driven tunnel vision, to check proposed regulations whose benefits do not justify their costs (or to help revise those proposals to better maximize net benefits) - though some argue that public choice theory implies that agencies will regulate too little. ${ }^{21}$ One response to the latter concern has been the innovation of 'prompt' letters, which were introduced, interestingly, in the George W. Bush administration, and which enable OIRA to ask an agency to consider adopting a new regulation (Graham 2007a).

The US has no IA process nor ROB to oversee Congressional legislation itself. Compared to the courts and the executive branch, Congress has played a smaller role in regulatory review. Congress holds periodic committee hearings on specific policy areas. The General Accountability Office (GAO) attached to the Congress issues occasional reports on regulatory matters. The Congressional Budget Office (CBO) estimates the impacts of new laws on federal government spending and revenues, but not usually on private sector costs and benefits. Congress did enact the Unfunded Mandates Reform Act (UMRA 1995), calling for nonbinding analyses of new regulations; the Congressional Review Act, authorizing expedited passage by Congress of a bill to rescind an agency regulation (though still requiring passage by both houses of Congress and signature by the President, hence rarely used); and a law calling for

20 Some US federal agencies are called 'independent', because the President's power to remove the agency head is restricted; it remains an unresolved question whether the President can require those agencies to comply with the IA process and OIRA oversight.

21 Compare Breyer (1993) (worrying about agencies' tunnel vision and excessive regulation), with Revesz and Livermore (2008) (worrying that agencies may regulate too little). 
annual reports by OMB/OIRA to the Congress on the aggregate costs and benefits of federal regulation over the last decade. But, in general, after having created OIRA, Congress has not strongly favored regulatory oversight - especially of its own legislative enactments. Congress has no ROB of its own equipped to carry out such a function. In the 1980s, some in Congress resisted the Presidency's efforts to oversee regulation through OMB/OIRA. The Congress considered, but not did enact, broad regulatory reform legislation in the mid-1990s. Congress even de-funded its own expert advisory bodies, the Office of Technology Assessment (OTA) and the Administrative Conference of the US (ACUS).

\subsection{The location of the IAB in the EU structure of government}

The EU has a hybrid system. In contrast to the US system, in which the roles of the principals (the Congress, the Presidency) and the agents (the federal agencies) are fairly easy to identify, with lateral oversight by the courts and internal oversight by the President's executive office (OIRA), in the EU the roles of principals and agents are more fragmented and interwoven across several institutions. These include the European Commission exercising internal oversight through its Secretariat-General, its interservice consultation practices, and its new IAB; the Council of the EU; the European Parliament; and the member states; with lateral oversight by bodies such as the European Court of Justice, the European Court of Auditors (which reviews the budget), and the European Ombudsman (which can investigate 'maladministration') (Lindseth et al. 2008, Alemanno 2009). ${ }^{22}$ Indeed, in the last ten years the European Commission has undertaken a sweeping effort to introduce better regulatory oversight mechanisms, mainly to further European economic competitiveness. ${ }^{23}$

The ROB in the EU that most closely corresponds to the US OMB/OIRA is the European Commission's relatively new Impact Assessment Board (IAB), created in late 2006, and located in the Commission's Secretariat-General under the direct authority of the Commission President. The IAB is composed of five high-level officials, in particular, the Deputy Secretary-General of the Commission, and four Directors coming from four Directorates-General: DG Enterprise and Industry, DG Environment, DG Employment, Social Affairs and Equal Opportunities, and DG Economic and Financial Affairs (Alemanno 2008). ${ }^{24}$ The IAB has some expert staff, but the five members meet periodically; and the DGs represented on the IAB may be proponents of policies being reviewed by the IAB. The IAB's location in the Commission is on its face similar to the location of US OIRA within the executive branch, but the European Commission's distinctive role as the sole institution empowered to introduce legislation gives its IA process oversight of legislative, rather than exclusively administrative, action. Thus,

22 Under Article 228 of the 2009 Lisbon Treaty on the Functioning of the European Union (TFEU) (former Article 195 EC), the Ombudsman may investigate complaints from EU citizens in instances of maladministration, 'with the exception of the Court of Justice and the Court of First Instance acting in their judicial role'.

23 See Lofstedt et al. (2008: 135) (observing that the EU has done more on regulatory reform from 1998-2008 than it had in all the years from 1956-97) and Wiener (2006).

24 To know more on the IAB, see Alemanno (2008). See also the Commission Staff Working Paper, 'Impact Assessment Board - Report for the year 2007', COM (2008) 32 final. 
the Commission has created an internal, quasi-specialized, executive/legislative ROB to oversee effective compliance by the Commission with IA requirements.

\subsection{Comparing oversight structures across the Atlantic}

The different approach to the structure of oversight in the EU system compared to the US derives from the different structures of governance. In the US, legislation begins in the Congress, a political body, which enacts statutes and can thereby create regulatory agencies and delegate tasks to these agencies. The agencies possess technocratic expertise that the Congress lacks, and Congress often relies on the agencies to determine essential issues such as the appropriate level of protection of health and environment. OIRA in turn is also a highly technical body, staffed by professional experts, that reports to the President. The heads of the agencies and the head of OIRA are all appointed by the President, but nonetheless it is sometimes a challenge for the Presidency to steer the policy direction of the agencies, each of which has its own constituencies among the public and in Congressional committees, and some of whose heads are legally shielded from being easily removed by the President. Regulatory oversight through OIRA is one means for the President to manage the multi-headed regulatory state (E. Kagan 2001). Thus in the US, OIRA is a politically accountable body that exercises technocratic review of regulatory power delegated by Congress to the federal agencies.

In the EU, by contrast, legislation begins exclusively in the Commission, which is mainly a technical executive body, although the political accountability and authority of the Commission's president is growing. (The Commission's President is not popularly elected like the US President, but rather is appointed by the European Council and subject to a vote of approval by the European Parliament.) 'Agencies' such as the European Environment Agency or European Food Safety Authority exist in the EU, but, being judicially barred from exercising delegated regulatory authority, ${ }^{25}$ their main function is to engage in preparatory executive acts under direct Commission oversight. ${ }^{26}$ Regulatory power is exercised by the DGs (such as DG Environment), subject to their proposals for Directives and Regulations being adopted by the full Commission. The Commission proposes new legislative initiatives to the Council and the Parliament, both political bodies. The Council is made up of the relevant ministers of the member states - a kind of legislature composed of national-level executives - and the Parliament is a large legislature composed of elected representatives, seated by party not by member state. The adage is that 'the Commission proposes, the Council disposes'. Yet these institutions also operate in a complex relationship of delegation and cooperation, the framework of 'comitology', that is, the committee system which oversees the delegated acts implemented by the European Commission (Saurer, Chapter 36, this volume).

25 Although the European Court of Justice recognized the need for delegated legislation in Meroni (case 9/56, Meroni v. High Authority), it limited significantly the possibility of delegating regulatory authority. The idea is that agency decisions should not entail any use of regulatory discretion beyond a purely technical evaluation of the applications against fixed criteria. For a recent critique of the 'Meroni doctrine', see Majone (2010).

${ }^{26}$ For an introduction to the EU Agencies, see Communication from the Commission, The Operating Framework for the European Regulatory Agencies, $\operatorname{COM(2002)} 718$ final; Interinstitutional Agreement on the operating framework for the European regulatory agencies, presented by the EC Commission, 25/02/05, COM(2005) 59 final; Gilardi (2002: 873), Chiti (2000). 
Moreover, within the Commission and its DGs, many staff and observers point to a tradition of collaborative harmony or collegiality rather than adversarial or hierarchical relations; the 'College of Commissioners' (each from a different member state, and appointed together as a slate) makes its decisions in a consensual style. This emphasis on harmony and collegiality may derive from several factors, among them the original purpose of the European Community to heal and unify the continent. This may also be related to the substantially smaller and more close-knit size of the Commission compared to the larger US multi-agency administration. This collegiality within the Commission stands in contrast to the more hierarchical relationship in the US executive branch between OIRA (and the White House generally) and the federal agencies it oversees. Although the IAB has the power to comment on the quality of the IA accompanying a DG's policy proposal, the IAB does not (yet) have the explicit power to reject a policy proposal - that power is held by the College of Commissioners as a whole. Perhaps the IAB's power to influence policy decisions will accrete over time, as the President of the Commission becomes more powerful (an issue currently in flux with the adoption of the Lisbon Treaty in late 2009) and as technocratic review of regulatory policy becomes more customary in Europe. Even today internal debates do occur. Whatever its origins, this collegial style may help explain the more limited powers of the IAB, compared to OIRA, to reject or 'return' impact assessments and policy proposals to the agencies (Allio 2007b: 5). On the other hand, the persuasive influence of the IAB's report may induce the proponent DG to improve its IA or its policy (Alemanno 2008: 70). The Secretariat-General may also issue a negative opinion on a policy. ${ }^{27}$ In the US, by contrast, there is a strong tradition of using adversarial debate to test and shape decisions, not only in courts but also in the executive and legislative branches (R. Kagan 2001).

Thus in the EU, the IAB reviews proposals from its own technical administrative branch of government (the Commission), in a setting that softens overt discord, before those proposals go to the political branches for assent (and then often to the member states for implementation). The structural role of regulatory 'oversight' is thus different in the EU, where legislation comes initially from the technical branch and where the Commission internally follows a collegial structure and style, than it is in the US. In the US, legislation comes initially from the most political branch, and the agencies occupy a position that, functionally at least, bridges the gap between the Congress and the Presidency. In the US, the ROB is a mechanism for the Presidency to manage the administrative state through technocratic expertise in a hierarchical structure.

\subsection{Plural ROBs}

Oversight need not be limited to a single ROB in each national or supranational administrative system. Plural oversight could involve several ROBs, each located in a different part of the regulatory structure. Indeed, the US has not only OIRA in the executive (and direct presidential power itself), but also interagency consultation, potent judicial review, numerous scientific advisory bodies, and always the possibility of a regulation being mandated or blocked by act of Congress, as well as a system of cooperative federalism with the 50 states. Meanwhile, the EU has the new IAB in the Commission, but also

27 See European Commission, Impact Assessment Guidelines, updated March 2006, pp. 14-15. 
aspects of oversight exercised by several other institutions, including inter-service consultation among the DGs, as well as the Council, the Parliament, the Ombudsman, the Court of Auditors, and the Court of Justice, and the 27 member states themselves. The optimal number and location of ROBs seem likely to differ from system to system and to depend on each polity's own constitutional features.

Oversight can also be located in networks of internal or external communities of experts. For example, interagency working groups can supply oversight. These include the former RARG in the Carter administration, and interagency consultation on proposed actions, as under the EU system of Inter-service Consultation, and the US system of interagency consultation on IAs submitted to OIRA. ${ }^{28}$ The European Commission IAB itself builds on the pre-existing system of inter-service consultation on DGs' impact assessments (Alemanno 2008, Allio 2007b). Additionally, external or quasigovernmental networks of nongovernmental experts, such as science advisory bodies, and public comment can provide influential advice (Jasanoff 1990, Morgan and Peha 2003, Graham 1991).

One can, of course, always ask if such external bodies actually influence government decisions. ROBs themselves may have external advisory bodies. For example, the UK Better Regulation (BR) Executive has had its BR Task Force, which then became the BR Commission, and is now being converted to the Risk and Regulation Advisory Council (OECD 2007a, chapter 3). Neither the US OIRA nor the EU IAB has a standing external advisory body, but such an external body has been called for by some members of the Commission ${ }^{29}$ and has recently been required by the European Parliament. ${ }^{30}$ Such calls could soon be amplified, should the European courts show any readiness to conduct judicial review of the EU Institutions' compliance with Better Regulation procedures. ${ }^{31}$

\section{Mandate and tasks}

\subsection{Mandate}

The mandate of any ROB is usually set forth in its enabling document. Its mission may be limited to quality control of impact assessments and other evaluative tools, or it may have the authority to inhibit undesirable policies (e.g. via 'return' letters), promote desirable policies (e.g. via 'prompt' letters), and conduct ex post (retrospective) evaluation in

28 This also includes interagency consultation on Environmental IAs submitted to EPA and CEQ under NEPA, and interagency consultation on biological opinions submitted to DOI/FWS under the Endangered Species Act.

29 Keynote Speech by Commissioner G. Verheugen, 'Better Legislation in the EU', delivered at the European Conference on Subsidiarity during the Austrian Presidency, April 19, 2006 ('what we need is the independent validation of impact assessment').

30 Report on Better Regulation in the European Union prepared by the Committee on Legal Affairs of the European Parliament (Rapporteur: Katalin Levai, 2007/2095(INI)) as a motion for an EP Resolution. See A6-0273/2007, para. 6.

31 For example, in Spain v. Council (2006), the European Court of Justice held that failure to produce an IA to support a regulatory decision may lead to a violation of the "proportionality' principle of EU law. See Case C-310/04, Kingdom of Spain v. Council of the European Union (2006) (holding that failure to conduct an IA might, in certain circumstances, be a breach of the proportionality principle); see Alemanno (2009). 
order to foster learning and policy revision. Ancillary missions may also include capacity building, training, and strategic planning of future policies.

The type of authority accorded to an ROB may depend importantly on the source of its authority, that is, on the institution that created the ROB. For example, authority conferred by a statute enacted by the legislature may have broader application to reviews of future legislation, whereas authority conferred by order of the President or Prime Minister may be confined to oversight within the executive branch, though this distinction itself depends on the constitutional structure of the government.

\subsection{Tasks}

Depending on their mandates, ROBs may perform a variety of functions or tasks. Neither OIRA's nor IAB's missions are limited to quality control. Although their priority task is to review the quality of impact assessments, they enjoy a larger array of powers. These include:

Inhibiting undesirable policies OIRA has sought to inhibit the adoption of undesirable policies since 1981 using return letters to the federal agencies. ${ }^{32}$ Unlike OIRA, the IAB has no veto power over the IAs conducted by the Commission DGs. However, the IAB may ask the relevant DG to resubmit a revised version of the original IA. ${ }^{33}$ Thus, while it is true that the IAB itself cannot veto a flawed IA draft, its (negative) opinion may produce some relevant, though indirect, effects on the outcome of the quality control process. In particular, the Secretariat-General may block an initiative if the IAB opinion has not been taken into account by the DG author of the IA. This may occur to the extent that the Secretariat-General, unlike the IAB, enjoys this sort of veto power.

The question is then how far ROBs may go in inhibiting undesirable policies. OIRA can issue return letters, but under the EO, the agency can then appeal to a more senior administration official (such as the Vice President or the White House Chief of Staff). Can the ROB go to court, or be challenged in court? In the US, courts usually do not enforce Presidential executive orders against executive agencies, but they will require agencies to abide by Congressional statutes, which may affect regulatory oversight in various directions (including enforcing legislative requirements to conduct IA, enforcing legislative prohibitions on some types of analysis, and enforcing legislative time limits on agency action notwithstanding ongoing OIRA review). As for the EU, the European Courts may be starting to enforce such requirements. ${ }^{34}$ Indeed, despite the Commission's efforts to dismiss any attempt to legalize the Better Regulation requirements, these requirements, by dictating a more informed and more inclusive method of decision-making, are expected to influence public expectations, thus encouraging stakeholders to act in order to ensure their implementation by the Commission. Not only are private parties willing to challenge the correctness of IAs carried out by the Commission services, but it may be that the ECJ is ready to rely on IAs to determine a possible breach of a general principle of law, such as the principle of proportionality (Alemanno 2009).

\footnotetext{
32 Executive Order 12866. See, in particular, section 6(b).

33 See IA Guidelines 2009, p. 10.

34 Case C-310/04, Kingdom of Spain v. Council of the European Union (2006) (holding that failure to conduct an IA is a breach of the proportionality principle); see Alemanno (2009).
} 
Promoting desirable policies OIRA began to issue 'prompt' letters to promote desirable new policies in $2001 .{ }^{35}$ Rather than being sent in response to the regulators' submission of a draft rule for ROB review, a 'prompt' letter is sent on the ROB's own initiative, and contains a suggestion for how the regulator (be it an agency or a DG) could improve its regulations. The prompt letter, at least as developed by OIRA, does not mandate agency action; it only suggests a prima facie case for action based on an initial benefit-cost assessment showing that such new agency action could increase net benefits. For example, one of OIRA's first prompt letters was to the US Food and Drug Administration (FDA), asking FDA to consider a new rule requiring the listing of trans-fat content on the nutrition labels on packaged foods.

Yet the issuance of prompt letters by OIRA has been episodic and ad hoc. There is not yet a system in place to help OIRA generate prompt letters as routinely as OIRA currently reviews agency proposals and potentially issues return letters. One option would be an external advisory body to OIRA, or a new panel of the National Academy of Sciences, or both, that would generate candidate prompt letters. ${ }^{36}$ An interagency working group could play a similar role. Another option would permit nongovernmental organizations to appeal to OIRA to issue a prompt letter if an agency denies a rulemaking petition (Revesz and Livermore 2008).

In Europe, the IAB's Mandate and Rules of Procedure also speak of 'prompt' letters, but, unlike in the US context, they are prompts to conduct an IA, not to develop a regulation. ${ }^{37}$ The current blanket application of IAs to all items on the Commission's Work Program (CLWP) does not necessarily cover all proposals with the most significant impacts. ${ }^{38}$ Hence prompt letters might have the potential to fill this gap. Following the establishment of the IAB, the Secretariat-General is in charge of identifying as early as possible items that are not included in the CLWP, but which could benefit from IA. When the IAB shares the opinion of the Secretariat-General, it may prompt, though not require, the relevant department to undertake an IA.

Information burdens and quality The ROB may also oversee the administrative burden of governmental requests for information. This was the objective of the US Paperwork Reduction Act of 1980 that created OIRA, and the original reason for the 'I' in OIRA. It is also the objective of the efforts at administrative burden reduction by many European governments. Meanwhile, the ROB may also oversee the quality of information produced by government agencies, as under the US Information Quality Act of 2001. ${ }^{39}$

35 OIRA has issued several prompt letters to agencies in this way since 2001. For more about the genesis and rationale of this device, see Graham (2007a). OIRA posts its prompt letters online at http://www.reginfo.gov/public/jsp/EO/promptLetters.jsp.

36 See Committee of Past Presidents, Society for Risk Analysis (SRA), Recommendations to OMB on Regulatory Review, March 16, 2009, Recommendation no. 7, p. 9, available at http://sra. org/OMB_regulatory_review.php.

37 IAB Mandate, point 4 and Article 6 of the IAB Rules.

38 Thus, for instance, among the initiatives which are not a priori subject to IA, there are nonpriority list CLWP items and certain implementing measures such as comitology decisions.

39 Information Quality Act of 2001, Pub. L. No. 106-554, § 515, codified at 44 USC 3516 (Note) (directing OMB to issue guidelines that 'provide policy and procedural guidance to Federal agencies for ensuring and maximizing the quality, objectivity, utility, and integrity of information 
Capacity building Both OIRA and the IAB are instructed to help agencies and DGs to perform better IAs. In particular, they may perform this task by issuing guidelines on how to conduct $\mathrm{IA}^{40}$ and also engage in early collaboration to shape the rule toward increasing net benefits - not just waiting to receive the proposed rule and then critiquing it. ${ }^{41}$

\section{Rules of procedure}

To fully exercise its tasks and discharge its mandate, any oversight body must act within the framework of a set of procedural rules. The specific rules of procedure of an ROB can be important in determining its effectiveness, quality, and perceived legitimacy (Rose-Ackerman 1995). US OMB/OIRA follows rules of procedure established in EO 12866, including rules regarding the timetable to review agency IAs, the transparency of OIRA's contacts with outside parties, and the opportunity for an agency to appeal an OIRA decision. EO 12866 (September 1993) replaced the earlier EO 12291 (February 1981), and significantly changed OIRA's rules of procedure, notably by requiring much greater transparency. The European Commission's IAB has rules of procedure issued in early 2007, governing the composition and voting of the five-member IAB, the timing of reviews of IAs, transparency of IAB deliberations, and sources of internal and external expertise. In addition, US OMB has guidelines for impact assessment, mainly in Circular A-4, September 2003, as does the European IAB, mainly in its IA Guidelines of January 15, 2009. OIRA also issued guidelines for good risk analysis (jointly with Office of Science and Technology Policy - OSTP, in September 2007).

\subsection{Leadership of the ROB: number and affiliation}

US OIRA is headed by a single Administrator, who is assisted by career staff members. By contrast, the EU IAB is a five-member board, chaired by the Deputy SecretaryGeneral responsible for regulatory matters, with four additional members who are senior officials of key DGs. ${ }^{42}$ The IAB's rules say that its members are supposed 'to act independently of the policy making departments' notwithstanding its members' affiliation of origin. ${ }^{43}$ This might seem odd to the extent that, besides the Deputy Secretary General who chairs it, the board's other four members are appointed by the Directors General heading the DGs to which these four IAB members belong. In other words, they are appointed to a body to oversee the DGs by their own bosses at the DGs. ${ }^{44}$ Yet, perhaps surprisingly, during its first four years of activity, the IAB has been perceived as reasonably impartial and independent. One may venture to suggest that the main driving force behind this positive development is a reputational factor: IAB members know that their professional future is linked to the success of the IAB; hence they have an incentive to defend their own name and expertise by privileging an impartial and consistent approach in analyses rather than acting to favour their home DGs.

\footnotetext{
... disseminated by Federal agencies'). OMB issued its guidelines in December 2001; see 67 Fed. Reg. 8452 (republication of February 22, 2002).

40 See OIRA Circular A-4 (September 2003), and the EU IAB Mandate 2005, point 6.

41 See Graham (2007); IA Guidelines 2009: 10; IA Rules of procedure, Article 5.3.

42 For a critique of the actual IAB membership, see Alemanno (2008: 70).

$43 \operatorname{COM}(2006) 689,8$.

44 See Article 1, para. 3, of the Rules of Procedures.
} 
It remains to be seen whether a five-member board can operate effectively to review IAs, compared to OIRA's single Administrator (irrespective of the home affiliations of the IAB members). The IAB's self-evaluation in early 2008 sought to allay these concerns. The audit exercise by the European Court of Auditors on the EU IA system, which is currently ongoing, is expected to provide some recommendations on the IAB's institutional membership. ${ }^{45}$

\subsection{Time to review}

In the US OIRA, the time for review extends up to 90 days from the receipt of a proposed rule. In the EU IAB, the time to review extends at least 30 days before inter-service consultation begins. Too short a time period may make meaningful review of complex IAs difficult or impossible. But too long a time period may impose unwarranted delay on needed new rules and may undermine morale. In the US in the late 1990s, a significant number of proposed rules had waiting times longer than 90 days. In 2001 and 2002, OIRA made substantial progress in reducing the time for review below 90 days. ${ }^{46}$ In 2008 , the IAB has uploaded its opinions on time in almost $80 \%$ of the cases. ${ }^{47}$

\subsection{Who can participate in review}

The EU IAB rules expressly allow the IAB to solicit advice from outside experts. OIRA can receive communications from parties outside government (so long as they are identified in its docket), but does not seem to have the standard practice of soliciting advice from outside experts. Both the IAB and OIRA have processes of inter-service (or interagency) consultation on proposed rules.

\subsection{Opportunity for the regulatory agency to be heard and to hear critiques}

EO 12866 calls for the agency proposing the rule to be invited to have a representative present whenever OIRA staff meet with an outside party about the rule. Under the IAB rules of procedure, during the meeting between the IAB and the author DG, the latter is represented by the head of the relevant unit and a support official.

\subsection{Appeals to higher authority}

EO 12866 provided that disputes over a return letter could be appealed to a cabinet-level committee chaired by the Vice President. Under the George W. Bush administration, this responsibility was shifted from the Vice President to the President's Chief of Staff. In the EU, a DG may appeal to the full Commission from an IAB opinion or SecretariatGeneral decision.

\subsection{Influence of statutory deadlines}

In the US, a statutory deadline or a court-ordered deadline for rulemaking will force the agency to act (e.g. to publish a rule) even if OIRA has not yet completed its review. A similar constraint does not exist in the EU, where IA is not mandatory, being

\footnotetext{
45 Council of the European Union, Conclusions of the Competitiveness Council on Better Regulation, December 3-4, 2009.

46 See US GAO (2003).

47 Impact Assessment Board Report for 2008 (2008: 9).
} 
contained not in statutes but in soft law acts, such as guidelines ${ }^{48}$ and where some IAs are conducted regarding the Commission's proposals for legislation which have no time deadline.

\subsection{Public access to information about the review}

Rules of procedure not only dictate each stage of the examination undertaken by the ROB, but also introduce transparency requirements. In the US, agency rulemaking is already public, pursuant to the APA, with notices of proposed rulemaking, proposed rules, and final rules all published in the Federal Register and now also online. EO 12866 added transparency provisions to ensure public awareness of the OIRA process, including a record of those who met with OIRA regarding each rule. During the George W. Bush administration, in contrast to efforts to withhold information in some other parts of the administration, OIRA went further than required by EO 12866 and posted all of its return letters, prompt letters, guidelines, and almost all other important documents on its public web site. ${ }^{49}$

In the EU, the location of IAB review in the regulatory process limits the transparency of its activities. Article 16 of the IAB Rules of Procedure seems to ensure transparency to the extent that it requires the Board to make available its draft agendas, meeting records, opinions, prompt-letters, and notes signed by the chair on behalf of the IAB as quickly as possible to all Commission departments. At the same time, it ensures public access to the Board's documents by subjecting them to principles and conditions as laid down in Regulation 1049/2001 regarding public access to European Parliament, Council and Commission documents. ${ }^{50}$ Although all IAB opinions must be available to all Commission services, ${ }^{51}$ they are released, through a publication on the IAB page within the Europa website, only when the Commission has adopted the corresponding proposal. This is automatically done by the IAB as the sole owner of its opinions. If the IAB opinions were to become public before the final adoption of the Commission proposal, this would lead to a situation in which an IAB opinion on a draft IA would be disclosed before the Commission proposal itself, thus inevitably disclosing the contents of the latter. However, the lack of publication of the draft IA report, combined with the delayed disclosure of its final version, make it difficult to determine, after the fact, the exact object and influence of the IAB review This may only be inferred by reading the published final IA report from the DG, in the light of the suggestions contained within the IAB opinion.

\section{Scope of oversight}

ROBs may address a wide array of regulatory activities, including proposals for new regulations, the stock of existing regulations, proposals for new statutes and legislative

\footnotetext{
48 On the legal status of RIA in the EU, see Alemanno (2009).

49 See the OIRA website at http://www.whitehouse.gov/omb/regulatory_affairs/default/, the OIRA Regulatory Matters website at http://www.whitehouse.gov/omb/inforeg_regmatters/, and US GAO (2003).

50 Regulation 2001/1049 of the European Parliament and of the Council of 30 May 2001, OJ L 145, p. 43.

51 Article 6 of the Rules.
} 
acts, information requests, and others. They may oversee the full span of government actors, or only a subset.

\subsection{Timing: ex ante and expost}

Most ROBs focus mainly on the flow of new regulations while giving less attention to the existing stock of rules. Thus, both US OIRA and EU IAB focus on ex ante impact assessment of new regulations, with only occasional attention to the stock of existing rules, or to retrospective ex post IAs of previously adopted rules. Yet, ex post review would be useful to identify needed policy revisions, and to assess and improve the accuracy of ex ante IAs (Wiener 2006, Harrington et al. 2000).

\subsection{Administrative costs}

Some ROBs do focus on the burden of existing rules and are less concerned with new regulations. Countries that have sought to reduce administrative burdens have taken this approach. Many employ the Standard Cost Model (SCM), compliance cost evaluations, 'simplification', and 'regulatory budgets' to reduce paperwork burdens. The Netherlands has been a leader in this area (OECD 2007b), but the UK has also made major strides in reducing administrative burdens on the private sector. ${ }^{52}$

Despite the widespread enthusiasm for cutting red tape, it is not always obvious that cutting administrative burdens is desirable. Subjecting administrative burdens to a benefit-cost test (as for other regulations) would be superior to simply enforcing arbitrary burden reduction targets. Information-based regulations can be warranted in some cases (OECD 2007b, Wiener 2006:500-01). The European Commission recognized this in its revised IA Guidelines on March 15, 2006, stating in Box 11 that:

The fact that one option would impose lower administrative costs is not in itself a sufficient reason to prefer it. For example, a measure . . . likely to impose relatively fewer administrative costs [by mandating specific technical standards, instead of requiring labels that disclose product data] . . . could give manufacturers less flexibility and could reduce consumer choice, [so that] its overall costs may be higher than the 'administrative' requirement to display data ...

Information collection and disclosure rules, such as product labelling, the US Toxics Release Inventory, and similar pollution discharge registries, may be especially costeffective ways to protect society (Hamilton 2005, Sand 2010).

\subsection{Topical areas of regulation}

In principle, an ROB could oversee all regulation, covering all topics. In practice, ROBs often focus only on one type of regulation, such as rules imposing administrative burdens (information collection costs). ROBs often focus on health, safety, security and environmental regulations (sometimes called 'social regulation' or 'risk regulation'), while sometimes having curtailed powers or less emphasis in the areas of banking, finance, competition, trade, and other 'economic regulation'. In some countries, sensitive areas such as defense or taxation/fiscal policy (Mexico, for example) are exempt from the review process.

52 See UK House of Commons, Regulatory Reform Committee, 'Getting Results: The BRE and its Regulatory Reform Agenda' (July 2008). 
Expanding the ROB's scope could bring the benefits of oversight to those areas and could also help correct the misimpression that oversight tools, such as benefit-cost analysis, are biased against the subjects of their current narrow application. For example, extending benefit-cost analysis beyond social regulation to cover economic regulation and government-funded projects would help demonstrate that benefit-cost analysis need not be biased against health or the environment. Benefit-cost analysis would then be deployed to assess environmentally damaging projects such as dams, deforestation, and power plants - as it had been in its early uses decades ago (Kneese 2000, Hufschmidt 2000). ${ }^{53}$ Early in the modern environmental movement, benefit-cost analysis was seen as a useful tool for environmental protection when applied to the evaluation of projects in the US and elsewhere. ${ }^{54}$ At the same time, expanding the scope of oversight could stretch ROBs' capacity, and could bring ROBs into conflict with other institutions already active in those areas.

In the US, OIRA has emphasized impact assessment of proposed new regulations addressing health, safety, and environmental risks. Over the last several years (at least since September 11, 2001), it began to address proposed new regulations of homeland security risks as well. On a related front, OIRA could expand its mandate to oversee international treaty commitments (via impact assessments); the US State Department has recently proposed requiring agencies to consult with OMB/OIRA on the regulatory impacts of pending new international agreements, ${ }^{55}$ and the State Department already requires agencies to consult with OMB before making new budgetary commitments in international agreements. ${ }^{56}$ In Europe, many ROBs at the national level consider the national impact of proposed EU-wide policies.

ROBs could extend their role further, addressing existing as well as new regulations. They could address decisions not to regulate, or to deregulate, as well as to regulate, ${ }^{57}$ and also assess economic policies and projects. For example, a US statute, section 201 of the Trade Act of 1974, 19 USC 2251(a), already calls for benefit-cost analysis of trade measures, but this law has not been implemented by OIRA. ${ }^{58}$

Another area of potential expanded scope for regulatory oversight is the banking, finance and insurance sector, as well as fiscal policies. In many countries, these policies are handled in a separate way and are not subject to regulatory quality oversight. For example, in the US, fiscal spending and taxation policy has traditionally been handled

53 See the Federal Flood Control Act of 1936 (requiring that the 'benefits to whomsoever they may accrue are in excess of the estimated costs', 33 USC $\S 701(\mathrm{a}))$.

54 See, for example, Berkman and Viscusi (1973) (using BCA to critique federal dams); Calvert Cliffs Co-ordinating Committee v. AEC, 449 F 2d 1109 (DC Cir 1971) (finding that the Environmental IA provision in NEPA section 102(2)(C) requires benefit-cost analysis of federal projects such as nuclear power plants, in order to take into account their previously neglected environmental costs), cert denied, 404 US 942 (1972).

5571 Fed. Reg. 28831 (May 18, 2006).

56 See 22 CFR $\$ 181.4(\mathrm{e})$.

57 See Revesz and Livermore (2008). This may already be the practice at OIRA.

58 See on this point, Review of the Application of EU and US Regulatory Impact Assessment Guidelines on the Analysis of Impacts on International Trade and Investment, Final Report and Conclusion, prepared by the OMB and Secretariat-General of the EU Commission, available at http://www.whitehouse.gov/omb/assets/regulatory_matters_pdf/sg-omb_final.pdf. 
by the budget side of OMB (and at the CBO), whereas OIRA is on the management side. Banking and finance regulatory agencies such as the Securities and Exchange Commission (SEC), the Department of the Treasury, the Federal Deposit Insurance Corporation (FDIC), the Comptroller of the Currency, and the Federal Reserve Bank have not been subject to regular OIRA oversight, although policies of the Department of Housing and Urban Development (HUD), which governs among other things the mortgage loans made by Fannie Mae, have been subject to OIRA review. The mortgage and credit crisis of 2008-10, and the dramatic move to restructure the banking and financial markets to rescue the economy from this crisis in the US and Europe, suggest that past choices by markets and regulators have been suboptimal, to say the least. This implies that this area could benefit from oversight on benefit-cost criteria by ROBs.

\subsection{Types of legal action}

ROBs differ in the type of legal action they oversee. This may include legislation, rulemaking, guidance documents and other avenues. Under section 3(b) of EO 12866, US OIRA oversight is limited to regulations promulgated by federal executive agencies. From January 2007 to January 2009, EO 13422 added review of guidance documents issued by these same agencies. By contrast, in Europe, the IA Guidelines and IAB oversight apply to legislation proposed by the European Commission, and indeed to all matters in the Commission's annual Legislative and Work Programme (CLWP). ${ }^{59}$ The nature of the US institutional system, with its separation of powers, precludes OIRA review from being meaningfully extended to cover legislation (although the executive branch could prepare IAs of pending legislation as a way to influence legislators or to inform the President's veto decisions). Perhaps a new ROB, attached to the Congress, could be established to supervise impact assessment of legislation proposed in the Congress. To the extent that agency regulations warrant oversight, in many cases a large share of their costs and benefits derive from the underlying legislation impelling the agency to issue that regulation. As noted above, CBO estimates the fiscal impacts of new laws on government spending and revenues, but does not focus on private costs and benefits. This underlines the need for IA and oversight of regulatory quality within legislatures. In many countries, finding an oversight mechanism to enable Parliament to conduct and heed impact assessments on its own legislative proposals, and ex post assessments of laws already enacted, could help fill significant gaps. The adoption of such a mechanism would, however, face political obstacles because it threatens to make transparent the distribution of costs and benefits posed by legislation. It is interesting to observe that a debate is currently under way in the EU on whether the scope of regulatory oversight should be narrowed because the current regime is suffering from its own success in producing too many IAs.

59 Some important decisions handled through 'comitology' may fall outside this scope of review, but the IAB is expressly authorized to reach out with a prompt letter to identify such decisions warranting an IA. See IAB Mandate, point 4, at http://ec.europa.eu/governance/impact/ docs/key_docs/iab_mandate_annex_sec_2006_1457_3.pdf. 


\subsection{Selection of which regulations to review}

Any ROB with limited oversight resources (staff, funding, time) must have some criteria for selecting which regulations to review. Most of the cost of conducting IAs falls on the agencies or DGs that wish to promulgate rules, because they prepare the initial IAs which the ROB (OIRA or the IAB) then reviews. But the ROB must also have the capacity, and some selection or triage mechanism, to use its own scarce resources effectively.

In the US, section 3(f) of EO 12866 makes the cut by using a threshold of the magnitude of impact, requiring an IA for any regulation imposing $\$ 100$ million or more in impacts. In 2003, OIRA added the criterion that any regulation posing an impact exceeding $\$ 1$ billion should be accompanied by an IA using formal probabilistic scenarios to assess its impacts.

The European Commission takes a different approach. Under its IA Guidelines, it employs the concept of 'proportionate analysis', meaning that the degree of analysis should be greater where the potential impacts of the regulation are larger. This approach avoids the sharp disjunctions and potential estimation errors of agencies' efforts to avoid review by undercounting impacts to come under the dollar-value thresholds used in the US. OIRA and the Office of Science and Technology Policy (OSTP) endorsed the concept of proportionate analysis in 2007 , saying 'The depth or extent of the analysis of the risks, benefits and costs associated with a decision should be commensurate with the nature and significance of the decision', ${ }^{60}$

\subsection{Analytic methods}

As discussed above, ROBs can employ a variety of analytic methods in their reviews, and can ask agencies to use these methods in their regulatory IAs. Statutory restrictions sometimes limit the type of analysis that an agency may use in making its regulatory decisions. For example, in the US, Congress has in some statutes required (or the courts so infer from statutory language) agencies to use benefit-cost analysis in developing rules, but in some other statutes Congress has forbidden agencies to use benefit-cost analysis. One example is the setting of national ambient air quality standards under section 109 of the Clean Air Act, where the courts have held that the statute forbids the US Environmental Protection Agency (EPA) to consider cost. ${ }^{61}$ In such cases, the agency still prepares an impact assessment using benefit-cost analysis for OIRA review under the EO, but the agency is not supposed to refer to or base its decisions on that analysis when it sets standards in the rule itself. ${ }^{62}$ In the early 1990 s, Congress considered but did not enact a law including a 'supermandate' to require benefit-cost analysis in all major rulemakings, notwithstanding prior statutory restrictions on such analysis. A different option would be a legislative 'superauthorization', permitting but not requiring agencies to use benefit-cost analysis in major rules notwithstanding prior statutory restrictions on such analysis. This approach was taken by Congress in one statute, the 1996 amendments to the Safe Drinking Water Act, but has not yet been employed more broadly. In

60 OMB/OIRA and OSTP Memorandum on Updated Principles of Risk Analysis, September 19, 2007 , p. 4.

${ }_{61}$ See Whitman v. American Trucking Assns., 531 US 457 (2001). Apart from section 109, some other parts of the Clean Air Act allow EPA to consider costs.

62 See Whitman v. American Trucking Assns., 531 US 457, 471 n. 4 (2001). 
effect, a superauthorization of the analytic methods used in impact assessment would stand for a straightforward idea: Let the regulators think things through.

In the EU, where legislation is initiated by the Commission, and the Commission has committed itself to conduct impact assessments, there are no restrictions in particular pieces of legislation on the use of impact assessments. The EU Commission's IA Guidelines require analysis of 'positive and negative impacts', but without imposing any specific methodology. The 2009 Lisbon Treaty on the Functioning of the European Union, Article 191, expressly calls for analysis of benefits and costs only in setting environmental standards. As a result, the IA conducted by DG Environment on the Clean Air for Europe (CAFÉ) policy - the EU counterpart of the US EPA's ambient air quality standards - was an extensive analysis of benefits and costs that many regard as one of the best quality IAs prepared by the Commission to date. ${ }^{63}$

\section{Conclusions}

As governments around the globe become increasingly conscious of the need for better policy making, they establish regulatory oversight bodies and entrust these bodies with the mandate to supervise the quality of regulatory analysis and action. As our review of US and EU practice has shown, an ROB must be designed to suit the constitutional framework within which it is institutionally housed and also the philosophy of the regulatory improvement initiative that motivates its existence. Thus, the salient differences between OIRA in the US and IAB in Europe derive in part from the different US and EU constitutional contexts, and from the different purposes of their respective IA systems. Impact assessment in the US and the EU is conducted and reviewed at different stages in the process, with different powers and limitations, and for different purposes. In the US, Congress instructs agencies to regulate; the President then requires agencies to conduct IAs to accompany proposed rules, and empowers OIRA, a body created by statute, to oversee the rules and to review the regulatory IAs. In the EU, IAs are conducted on a voluntary basis by the Commission, on all its policy and legislative proposals, and largely for its internal use; the IAs are then reviewed by the IAB within the Commission. As a result, whereas IA serves as an executive branch check on the exercise of legislatively delegated powers in the US system, it functions as a support for proposed legislation in the EU.

These features explain in part why the IAB appears to be a weaker regulatory gatekeeper than OIRA. The US oversight body, having been conceived as a watchdog on legislative (Congressional) pressure on agencies to regulate, was designed with a single head and entrusted with the power to issue return letters on proposed rules or IAs. It has since begun to issue 'prompt' letters to spur beneficial new policies (rather than only checking proposals by the agencies). By contrast, the IAB, having been entrusted with improving the quality of legislative proposals, has an internal, multi-member, institutionally dependent representative board whose powers are mainly the ability to recommend that an IA should be redone and resubmitted to the IAB, and to communicate its views to the collegial Commission. Indeed, lacking veto power, the IAB cannot block, as could

63 See CAFE references documents, at http://ec.europa.eu/environment/archives/cafe/general/ keydocs.htm. 
OIRA, a DG draft IA or a policy proposal. Although the IAB appears by comparison with OIRA to be a weaker regulatory oversight body, its role is amplified when seen in the context of the overall quality control mechanisms within the Commission. ${ }^{64}$ The IAB opinions may affect the policy outcome if they are invoked at the end of the review process by the Secretariat-General (or by a member of the Commission, or another EU institution) to question the underlying policy initiative. Moreover, the mere existence of the IAB seems to encourage DGs to better prepare their IAs to avoid a negative opinion. More broadly, the general availability of IAB opinions may encourage and support objections raised by concerned stakeholders or other institutions. The IAB may be exercising a sort of 'soft power' within the existing oversight system. Although the long-term indirect effects of the IAB opinions are difficult to predict, it is likely that these opinions will strengthen the overall effectiveness of the quality review system. The European regulatory oversight body seems designed to provide compliance incentives for the actors involved in the regulatory oversight process, consistent with the view that 'to be effective, a system of regulation must create compliance incentives for regulated parties, rather than rely on corrective action and oversight' (Elliott 1994).

Nevertheless, though the IAB has the potential to become the main 'regulatory gatekeeper' within the EU quality control system, it does not yet have the explicit authority to return or to prompt policy proposals. Moreover, it does not currently appear to be adequately equipped to undertake technically sophisticated reviews of DGs' IAs or policy proposals, mainly due to: (a) the lack of effective rules ensuring the independence of IAB members; (b) too few resources to effectively undertake its mission; (c) a scarcity of staff with technical expertise in impact assessment methodologies and in other disciplines relevant to the oversight activities; (d) the lack of retrospective evaluations to improve on the quality of its own opinions; and (e) insufficient time to conduct careful reviews. While there is no doubt that the current IAB's members are among the best IA experts among high-level officials within the Commission departments, the current appointment rules do not seem to ensure that this result will be attained in the future. At the same time, the IAB should take advantage of its opportunities to seek both 'internal' and 'external' expertise, and it should develop its own technical capabilities through the appointment of specialized staff in the field of economic, environmental and social impact assessment in order to strengthen its in-house expertise and, simultaneously, enhance its independence from the DGs it oversees.

Meanwhile, OIRA has been equipped with the explicit authority and expert staff to carry out its traditional reviews and 'return' letters in response to ex ante IAs on agency proposals. In recent years, OIRA has moved to broaden its scope toward: earlier involvement with the agency in developing a sound proposal; later ex post reviews of IAs to improve policies and improve assessment methods; 'prompt' letters that promote good regulation; and oversight of a wider array of types of regulation. The new EO anticipated from President Obama may point OIRA in new directions, roles, and analytic methods.

The emergence of ROBs in both the US and, more recently, the EU demonstrates the new transatlantic consensus on the desirability of regulatory oversight, at least at

64 For an analyses of the overall quality control mechanisms existing within the Commission, see Alemanno (2008: 45-6). 
the centers of government. An open question deserving further study is how effective the ROBs are at improving the quality of IAs and of regulatory policies. Does 'better regulation' actually yield better regulation ${ }^{65}$ Each polity can now learn from the other's experience to improve its performance. Where differences or disagreements arise, those can be addressed through dialogue and through careful comparison. Differences can be sources of insight and learning if their impacts are monitored, evaluated and shared over time. In that way, the US and EU can use the parallel development of their ROBs to engage in a 'transatlantic policy laboratory' that yields better regulatory results for both (Wiener 2010, 2009).

\section{References}

Ackerman, Bruce A. 1993. We the People: Foundations, Cambridge, MA: Harvard University Press.

Ackerman, Bruce A. 1998. We the People: Transformations, Cambridge, MA: Harvard University Press.

Ackerman, Bruce A. and William T. Hassler. 1981. Clean Coal/Dirty Air, New Haven, CT: Yale University Press.

Adler, Mathew and Eric Posner, eds. 2001. Cost-benefit Analysis, Chicago: University of Chicago Press.

Adler, Matthew and Eric Posner. 2006. New Foundations of Cost-benefit Analysis, Cambridge: Harvard University Press.

Alemanno, Alberto. 2008. 'Quis Custodet Custodes dans le cadre de l'initiative Mieux Légiférer? Une analyse des mécanismes de surveillance règlementaire au sein de la Commission et la création du Comité d'évaluation des études d'impact, Revue du droit de l'Union européenne 1: 43-86.

Alemanno, Alberto. 2009. 'The Better Regulation Initiative at the Judicial Gate - A Trojan Horse within the Commission's Walls or the Way Forwards'? European Law Journal, 15: 382-401.

Allio, Lorenzo. 2007a. 'Better Regulation in the European Commission', in C. Kirkpatrick and D. Parker, eds., Regulatory Impact Assessment: Towards Better Regulation?, Cheltenham UK and Northampton, MA, USA: Edward Elgar Publishing.

Allio, Lorenzo. 2007b. 'The European Commission's Impact Assessment Board: Initial Developments', European Risk Forum Background Note 02, 5.

Allio, Lorenzo. 2008. 'Impact Assessment in the European Commission: An Evaluation', unpublished paper prepared for the European Policy Centre, Brussels.

Bagley, Nicholas and Richard L. Revesz. 2006. Centralized Oversight of the Regulatory State, Washington, DC: AEI-Brookings.

Berkman, Richard L. and W. Kip Viscusi. 1973. Damming the West: Ralph Nader's Study Group Report on the Bureau of Reclamation, New York: Grossman Publishers.

Beslier, S. and P. Lavaggi 2006. 'Les procédures de codification et de refonte en droit communautaire: une contribution à l'effort de simplification de l'environnement réglementaire', Revue du droit de l'Union européenne, 2: 313 .

Bickel, Alexander. 1986. The Least Dangerous Branch: The Supreme Court at the Bar of Politics, 2nd edition, Indianapolis: Bobbs-Merrill.

Bouder, Frederic. 2008. 'France', in Frank Frick and Tobias Ernst, eds., International Regulatory Reform Report 2008, Gütersloh: Verlag Bertelsmann Stiftung, 21-39.

Breyer, Stephen G. 1993. Breaking the Vicious Circle: Toward Effective Risk Regulation, Cambridge, MA: Harvard University Press.

Calvert Cliffs Co-ordinating Committee v. AEC, 449 F 2d 1109 (DC Cir 1971).

Caretti, P. and U. De Siervo. 1996. Istituzioni di diritto pubblico, Torino: Giappichelli.

Cecot C., Robert Hahn and Andrea Renda. 2007. 'A Statistical Analysis of the Quality of Impact Assessment in the European Union', AEI-Brookings Joint Center Working Papers, 07-09, May, Washington, DC.

Chiti, E. 2000. 'The Emergency of a Community Administration: The Case of European Agencies', Common Market Law Review, 37: 309-42.

Committee of Past Presidents. 2009. Society for Risk Analysis (SRA), Committee of Past Presidents, Recommendations to OMB on Regulatory Review, March 16, 2009, available at http://sra.org/OMB regulatory_review.php.

65 Empirical assessments of the impact of OIRA oversight, finding modest but beneficial influence, include Croley (2003) and Hahn and Muething (2003). 


\section{Comparative administrative law}

Croley, Steven P. 2003. 'White House Review of Agency Rulemaking: An Empirical Investigation', University Chicago Law Review, 70: 821-85.

Crowe, G. 2005, 'Tools for the Control of Political and Administrative Agents: Impact Assessment and Administrative Governance in the European Union', in H.C.H. Hoffman and A.H. Turk, EU Administrative Governance, Cheltenham, UK and Northampton, MA, USA: Edward Elgar Publishing.

Deighton-Smith, Rex. 2006. Determinants of Quality in RIA, Paris: OECD, December.

Deighton-Smith, Rex. 2007. Methodological Frameworks for RIA: Valuation, Risk and Cost-benefit Analysis, Paris: OECD, December.

Elliott, E. Donald. 1994. 'TQM ${ }^{5}$-ing OMB: Or Why Regulatory Review under Executive Order 12,291 Works Poorly and What President Clinton Should Do about it', Law \& Contemporary Problems, 57: 167-184.

Gilardi, F. 2002. 'Policy Credibility and Delegation to Independent Regulatory Agencies: A Comparative Empirical Analysis', Journal of European Public Policy, 9: 873-93.

Graham, John D. 1991. Harnessing Science for Environmental Regulation, New York: Praeger.

Graham, John D. 2007a. 'The Evolving Regulatory Role of the U.S. Office of Management and Budget', Review of Environmental Economics \& Policy, 1: 171-91.

Graham, John D. 2007b. Appendix 3, in OECD, Implementing Regulatory Reform: Building the Case through Results, Paris: OECD, December.

Graham, John D. 2008. 'Saving Lives through Administrative Law and Economics', University of Pennsylvania Law Review, 157: 395-540.

Graham, John D. and Jonathan B. Wiener, eds. 1995. Risk vs. Risk: Tradeoffs in Protecting Health and the Environment, Cambridge, MA: Harvard University Press.

Hahn, Robert W. and Robert E. Litan. 2005. 'Counting Regulatory Benefits and Costs: Lessons for the U.S. and Europe', Journal of International Economic Law, 8: 473-508.

Hahn, Robert W. and M. Muething. 2003. 'The Grand Experiment in Regulatory Reporting', Administrative Law Review, 55: 607-42.

Hahn, Robert and P.C. Tetlock. 2007. The Evolving Role of Economic Analysis in Regulatory Decision Making, Washington, DC: AEI-Brookings, November.

Hamilton, James T. 2005. Regulation through Revelation, Cambridge, UK: Cambridge University Press.

Harrington, Winston, Richard D. Morgenstern and Peter Nelson. 2000. 'On the Accuracy of Regulatory Cost Estimates', Journal of Policy Analysis and Management, 19: 297-332.

Hufschmidt, Maynard M. 2000. 'Benefit-cost Analysis: 1933-85', Water Resources Update, 116: 42-9, at http:// www.ucowr.siu.edu/updates/116/index.html.

Jacob, Klaus and Axel Volkery. 2004. 'The Environmental Dimension of Impact Assessment', Documentation of a Workshop organised together with the Federal Ministry for the Environment Nature Conservation and Nuclear Safety, FUB Report No. 01-2005, Berlin: Free University of Berlin (FUB) - Otto Suhr Institute for Political Science and European Environment Agency, at http://papers.ssrn.com/sol3/papers. cfm?abstract_id $=928347$.

Jasanoff, Sheila. 1990. The Fifth Branch: Science Advisers as Policymakers, Cambridge, MA: Harvard University Press.

Kagan, Elena. 2001. 'Presidential Administration', Harvard Law Review, 114: 2245-319.

Kagan, Robert A. 2001. Adversarial Legalism: The American Way of Law, Cambridge, MA: Harvard University Press.

Kneese, Alan V. 2000. 'Whatever Happened to Benefit-cost Analysis?', Water Resources Updates, 116: 58-61, at http://www.ucowr.siu.edu/updates/116/index.html.

Kolko, Gabriel. 1965. Railroads and Regulation 1877-1916, New York: W.W. Norton.

Lee N. and C. Kirkpatrick 2004. 'A Pilot Study of the Quality of European Commission Extended Impact Assessments', IARC Working Paper Series No. 8, Manchester, UK: University of Manchester.

Lindseth, Peter L., Alfred C. Aman and Alan C. Raul. 2008. Administrative Law of the European Union: Oversight, edited by George A. Bermann, Charles H. Koch and James T. O'Reilly, Chicago, Ill: ABA.

Lofstedt, Ragnar, J. Torriti and F. Bouder. 2008. 'Key Lessons and Recommendations', in Frank Frick and Tobias Ernst, eds., International Regulatory Reform Report 2008, Gütersloh: Verlag Bertelsmann Stiftung, $135-147$.

Lussis B. 2004. 'EU Extended Impact Assessment Review', Institut pour un Développement Durable Working Paper, December, Ottignies, Belgium.

Majone, Giandomenico. 2010. 'Foundations of European Risk Regulation', European Journal of Risk Regulation, 1(1): 5-19.

Mather, G. and F. Vibert. 2006. 'Evaluating Better Regulation: Building the System', City Research Series, London: European Policy Forum.

Mistò, M. 2003. 'La collégialité de la Commission européenne', Revue du Droit de l'Union Européenne, 189206.

Morgan, Granger and John Peha. 2003. Science and Technology Advice for Congress, Washington: RFF Press. 
Obradovic, Daniela and Alonso Vizcaino, José. 2006. 'Good Governance Requirements Concerning the Participation of Interest Groups in EU Consultation', Common Market Law Review, 43: 1049-85.

OECD. 2007a. Implementing Regulatory Reform: Building the Case through Results, Paris: OECD.

OECD. 2007b. Cutting Red Tape: Administrative Simplification in the Netherlands, Paris: OECD.

OECD. 2009. Regulatory Impact Analysis - Tool for Policy Coherence, Paris: OECD.

Olson, Mancur. 1971 [1965]. The Logic of Collective Action, Cambridge, MA: Harvard University Press.

Radaelli, Claudio. 2004. 'The Diffusion of Regulatory Impact Analysis in OECD Countries: Best Practices or Lesson-drawing?', European Journal of Political Research, 43: 723-747.

Radaelli, Claudio and F. De Francesco. 2007. Regulatory Quality in Europe: Concepts, Measures, and Policy Processes, Manchester: Manchester University Press.

Renda, Andrea. 2006. Impact Assessment in the EU: The State of the Art and the Art of the State, Brussels: CEPS Paperbacks.

Revesz, Richard L. and Michael A. Livermore. 2008. Retaking Rationality, Oxford: Oxford University Press. Robineau, Y. and D. Truchet. 2002. Le Conseil d'Etat, Paris: PUF.

Rose-Ackerman, Susan. 1995. Controlling Environmental Policy: The Limits of Public Law in Germany and the United States, New Haven, CT: Yale University Press.

Sand, Peter H. 2010. 'Information Disclosure Systems', in Peter H. Sand, Jonathan B. Wiener, Michael D. Rogers, and James K. Hamilton, eds., The Reality of Precaution: Comparing Risk Regulation in the US and Europe, Washington, DC: RFF Press/Earthscan.

Shapiro, Stuart. 2006. 'Politics and Regulatory Policy Analysis', Regulation, Summer: 40-45.

Trosa, Sylvie. 2008. La réforme de l'Etat: un nouveau management?, valeurs et enjeux, Paris: Ellipses, Collection Transversale-débats.

Tushnet, Mark. 1995. 'Policy Distortion and Democratic Debilitation: Comparative Illumination of the Countermajoritarian Difficulty', Michigan Law Review, 94: 245-301.

US General Accountability Office (GAO). 2003. 'Rulemaking: OMB's Role in Reviews of Agencies' Draft Rules and the Transparency of those Reviews', GAO-03-929, September.

US OMB and Secretariat-General of the European Commission. 2005. 'Review of the Application of EU and US Regulatory Impact Assessment Guidelines on the Analysis of Impacts on International Trade and Investment, Final Report and Conclusion', available at http://www.whitehouse.gov/omb/assets/regulatory_matters_pdf/sg-omb_final.pdf.

US OMB/OIRA and OSTP. 2007. 'Memorandum on Updated Principles of Risk Analysis', Washington, DC, September 19.

Verschuuren, J. and R. van Gestel. 2009. 'Ex Ante Evaluation of Legislation: An Introduction', in J. Verschuuren; The Impact of Legislation: A Critical Analysis of Ex Ante Evaluation, Leiden and Button, MA: Martinus Nijhoff Publishers, 3-4.

Vibert F. 2004, The EU's New System of Regulatory Impact Assessment - A Scorecard, London: European Policy Forum.

Wiener, Jonathan B. 2003. 'Whose Precaution After All? A Comment on the Comparison and Evolution of Risk Regulatory Systems', Duke Journal of International and Comparative Law, 13: 207-62.

Wiener, Jonathan B. 2006. 'Better Regulation in Europe', Current Legal Problems, 56: 447-518.

Wiener, Jonathan B. 2009. 'Toward a Global Policy Laboratory', remarks at the SRA-RFF conference on New Ideas for Risk Regulation, 22 June.

Wiener, Jonathan B. 2010. 'The Real Pattern of Precaution', in Jonathan B. Wiener, James K. Hammitt, Michael D. Rogers and Peter H. Sand, eds., The Reality of Precaution: Comparing Risk Regulation in the US and Europe, Washington, DC: RFF Press/Earthscan, forthcoming.

Wiener, Jonathan B. and Barak Richman. 2010. 'Mechanism Choice', in Daniel Farber and Anne Joseph O'Connell, eds., Public Choice and Public Law, Cheltenham, UK and Northampton, MA, USA: Edward Elgar. 